Previous: Pushing Boundaries and Exploring Limits: Ami McKay's The Birth House as (Hys)torical Fiction by Judith Mintz

Next: "Can We Get a Cleanup On Aisle 2?": How Film Critics Mopped Up the Transgressions of Jenny McCarthy's Dirty Love by Sara Swain

\title{
The Antisocial Fantasies of Jude the Obscure
}

Matthew Risling

Pivot is published through Open Journal Systems (OJS) at York University 
In the original 1895 preface to Jude the Obscure, Thomas Hardy offered a concise statement of the text's purpose: "For a novel addressed by a man to men and women of full age; which attempts to deal unaffectedly with the fret and fever, derision and disaster, that may press in the wake of the strongest passion known to humanity, and to point without a mincing of words, the tragedy of unfulfilled aims" (38). Nearly The Antisocial Fantasies of thirty years later, in the Jude the Obscure preface to the 1912 edition of Jude, Hardy Matthew Risling quietly repurposed his novel. Where once the goal was to explore "the tragedy of unfulfilled aims," it now offered, "to tell, without a mincing of words, of a deadly war waged between the flesh and spirit" (39). Suddenly, Hardy's 1895 claim not to be mincing words starts to seem disingenuous; "unfulfilled aims" now feels like a cautious misdirection, shifting the primary focus of the novel away from Jude's vexed sexual relationships with Arabella Donn and Sue Bridehead to his frustrated attempts to gain entrance into Christminster University (a thinly veiled stand-in for Oxford). It is as though the sexuality at the core of the novel had until now been hiding behind a pretence that the main conflict lay in Jude's lack of social mobility. Certainly, we cannot ignore the looming presence of Christminster throughout the novel, but neither should we overlook the fact that we are less than one third of the way through when Jude reconciles himself to the impossibility of this dream. Read in this light, it can seem as though Hardy's revision attempts to bring the true purpose of the novel to light, to reveal what he was heretofore unwilling or unable to admit: that his novel had always really been about the problem of regulating our desires, bringing our sexual urges in line with a society that was preoccupied with denying their very existence. It is certainly 
true that Hardy used Jude the Obscure to enter into timely discussions of sexuality as part of the human experience. I will argue, however, that the novel does not so much try to obscure this discussion behind the Christminster plot, as it presents the two as inexorably linked. Simply put, Jude's academic and romantic ambitions are embodiments of the same antisocial fantasy.

By "antisocial" I do not mean that Jude thinks or acts in ways hostile to other individuals-although his unsanctioned ambitions certainly set him apart from society in a way that is continually perceived as hostile. Instead, I mean that he refuses to participate in the shared fantasies that stabilize interpersonal relations, establish ideological commonalities, and, from a psychoanalytical perspective, mask the traumatic impossibility of a complete social relationship. What makes Jude's spiritual and sexual fantasies antisocial, is that both, at least tacitly, acknowledge the absence upon which all social fantasies are constructed; he recognizes Christminster and Sue Bridehead as unattainable phantoms, which is what attracts him to them. They insist upon sociality's fundamental lack, denying the promise of future completion that underwrites all fantasy structures. Thus, the novel's main tension is not so much between the flesh and spirit as between the social and the antisocial. Jude's communities must ensure that these fantasies remain unfulfilled, because to fulfill them would be to threaten the social fantasy writ large and the ideological structures it maintains.

Hardy scholars have written much on the reason for the above revision. Rosemary Sumner, in the first book-length study of Hardy as a psychological novelist, suggests that he made this change as a way of defiantly foregrounding his long-held, though never fully articulated, belief in "the sexual basis of much psychological disturbance" (3). Conversely, James Harding argues that Hardy's revised preface was born of his 
(ultimately ineffectual) attempt to retreat from controversy; it was but one element in a larger process of revision in which he attempted to excise much of the overt sexuality from the novel. Ironically, as Harding notes, Hardy's plea for tolerance took on a peculiar character when read against the larger text:

Although it remained with the manuscript, the plea expressed in the "Preface" was now obsolete. The need for it had been invalidated by Hardy's own hand because "a mincing of words" in the form of significant revisions now skewed the "deadly war between flesh and spirit." (87)

Rather than seeing these proposed reasons for revision as oppositional-he is either foregrounding or backgrounding the novel's sexuality-I suggest that we read them as complementary. That is, this curious choice that Harding brings to our attention, to simultaneously announce the novel's sexuality in the preface while eliding it from the text, indicates a pervasive tension throughout the novel between Jude's social identities as a scholar and a lover. Neither can exist in isolation from the other: they are part of a continuum. The fact that Hardy's phrasings in the prefaces are nearly identical only serves to underscore this point.

While Hardy claims to be working within a larger religiousphilosophical tradition that sets the spirit and the flesh in binary opposition to each other, the novel itself continually undermines this binary. In fact, nowhere do we see either the veneration of the spirit or the condemnation of the flesh. Instead, Hardy offers us an exploration of a society that is as invested in policing aberrant spirituality as it is in policing aberrant sexuality. Here I understand "spirituality" as an ideological construct no less materialist in its foundation than any other social institution, and I think Hardy would agree. Indeed, he takes pains to show his reader that Jude's desire to attend Christminster is entirely secular. It is not based on some divine calling, but instead on Jude's pre-existing status 
as an outsider in the rural community of Marygreen. The fantasy, then, is constitutively aberrant since its inception is rooted in Jude's antisociality.

As Francesco Marroni observes, it is of no small significance that the novel opens as it does with the departure of Richard Phillotson, Jude's schoolmaster, surrogate father, and the closest thing he has to a friend: "For a boy like Jude, who had in Phillotson his only friend and affective and cultural reference point, the parting implies an acute suffering and a first warning of the instability of human relationships" (164). In other words, the fantasy arises at the precise moment that Jude encounters sociality's lack: the moment when he can no longer deny the impermanence of social relations. In psychoanalytic terms, this societal lack is to be understood not simply as an imperfection (imperfectability) in any external social structure, but, rather, a lack that exists first and foremost within the subject. This is what underlies Lacan's principle, introduced in Seminar $X X$, that there is no sexual relationship; there is no way to experience another individual except through the prismatic lens of the symbolic order, which necessarily prevents us from experiencing each other (or, indeed, ourselves) except as vessels for some ever-elusive psychic surplus. Philloston's departure from Marygreen enacts the primal fall, in which Jude is torn from the false promise of social relations and cast into the alienating order of the symbolic. It is at this moment that it becomes imperative for Jude to find that objet a-that ever-elusive piece of the "Big Other" which carries the social surplus that can never be satisfied.

Importantly, Phillotson introduces Christminster as an elusive object. When Jude asks, "Why do you go, sir?" Phillotson replies, "You wouldn't understand my reasons, Jude. You will, perhaps, when you are older" (46). Thus, Jude comprehends Christminster as a specter only, a city perpetually on the 
horizon, calling to him along the wind, "We are happy here!" (59). In psychoanalytic terms, this insubstantiality is crucial because the objet a must never become too tangible. It must always remain at arm's length because once it becomes too real it can no longer carry its social surplus. As Slavoj Žižek writes in Sublime, "we search in vain for it in positive reality because it has no positive consistency-because it is just an objectification of a void" (95). For Jude, then, Christminster becomes the ultimate objet a towards which his desires will always propel him, but which must always elude him. That he is continually denied entry into Christminster, by his fellow villagers when he is young and later by the institution itself, only serves to heighten its allure.

When Philloston abandons Jude, he imbues Christminster with the surplus that he himself can no longer bear. He does not so much offer Christminster as an object for Jude's desire as he offers Christminster as that which had always been this elusive object. As Jude realizes in the wake of Philloston's departure, a Christminster education promises him that which he has suddenly desired all along:

Jude continued his walk homeward alone, pondering so deeply that he forgot to feel timid. He suddenly grew older. It had been the yearning of his heart to find something to anchor on, to cling to-for some place which he could call admirable. Should he find that place in this city if he could get there? Would it be a spot in which, without fear of farmers, or hindrance, or ridicule, he could watch and wait and set himself to some mighty undertaking like the men of old of whom he had heard? (62)

As Hardy demonstrates, there is nothing in Christminster itself that calls to Jude. Instead, Hardy emphasizes the fundamental arbitrariness of Jude's spiritual aims. The fact that it had already been the yearning of Jude's heart to find something, 
and that Christminster just happened to fill the void, leaves us ample room to doubt whether it is a tragedy that these aims remain unfulfilled.

As noted, Jude's spiritual fantasy, his Christminster fantasy, is constitutively aberrant since it is rooted in Jude's antisociality. I do not simply mean that it is antisocial to the extent that all fantasies are antisocial, since they necessarily mark sociality's fundamental lack; rather, there is something in this peculiar fantasy that the Marygreen society finds threatening. It is not long before Jude's private studies become off-putting for those in his rural community, which is manifested as a generalized alienation from a community that now regards him as "very stuck up, and always reading" (79). Jude's apparent obliviousness to his community's silent disapprobation only functions to escalate the intensity of its social regulation. In a very telling episode, his insistence on pursuing his scholarly aims while working (as Hardy notes, the only study time available) results in his community calling for police intervention:

He was frequently met in the lanes by pedestrians and others without his seeing them, and by degrees the people of the neighbourhood began to talk about his method of combining work and play (such as they considered his reading to be), which, though probably convenient, was not altogether a safe proceeding for other travelers along the same roads.... [A] private resident of adjoining place informed the local policeman that the baker's boy should not be allowed to read while driving. (69)

While the neighbour's concern is ostensibly that of public safety, there is little indication that anyone was all that concerned with Jude's driving. The fact that he does not see pedestrians is initially regarded as a curiosity rather than a hazard. But eventually the community comes to recognize the fact of his not seeing them as a threat beyond the immediate 
possibility of a collision. It indicates a larger non-alignment, an uppitiness that marks him as a social outsider and a threat.

In his oft-cited introduction to the New Wessex edition, Terry Eagleton argues that Jude's conflict with his native and adoptive communities is rooted in class ideologies. For Eagleton, Jude's fantasy of becoming a Christminster scholar is disruptive because it entails moving beyond the confines of class limitations. It is not, he assures us, simply about moving upwards within capitalism; rather, it is about finding labour autonomy within such a heavily regulated economic system: "[Jude's] place in Marygreen society ... is with the semiindependent 'tradesman' class.... As a class, they offered a peculiarly intense focus for the disruptive social forces at work in the countryside" (37). Marygreen is not structured as a precapitalist peasant village. In fact, it is the opposite. It is a formerly trades-based agrarian economy "stripped of its thatched and dormered dwelling-houses as the tradesmen, craftsmen and lifeholders move from the land" (Eagleton 37). Mobility alone is not threatening to the Marygreen community; in fact, mobility is becoming the norm. Arabella, for instance, freely moves across the country, and even back and forth between England and Australia, without social disapprobation. What makes Jude's desire for mobility threatening is that he imagines scholarship at Christminster as a way of stepping outside capitalism altogether. Of course, this naïve fantasy is doomed from the start. As Eagleton notes, the bitter irony is that Christminster can only retain its phantasmal appeal by barring entry to tradesmen such as Jude, on whom it relies to maintain its crumbling edifice: "Jude's labour-power is exploited literally to prop up the structures which exclude him" (39). In other words, neither Marygreen nor Christminster care where Jude moves so long as his labour remains bound by the structures of capitalism. While Eagleton's analysis remains compelling, and certainly provides a convincing explanation for the university's investment in barring him entry, it does not 
adequately address the antisociality of Jude's dream, nor does it fully explain why the Marygreen community-one that is used to losing its young tradesmen to larger urban centers-so adamantly opposes his Christminster fantasy. In order to understand this, we must look more closely at the peculiar (or better, queer) nature of the fantasy.

Expanding upon methodologies set forth in Freud's Interpretation of Dreams, Žižek writes that the key to interpreting any fantasy lies in the shape that the fantasy assumes: "the point is to avoid the properly fetishistic fascination of the 'content' supposedly hidden behind the form: the 'secret' to be unveiled through analysis is not the content hidden by the form ... but, on the contrary, the 'secret' of the form itself" (SOI 11, italics in the original). Along these lines, then, in order to properly understand the antisocial nature of Jude's Christminster fantasy, we must examine the secret in the Christminster form that so captures Jude's imagination. I have touched on some of the key elements of this form already. In the first place, as the Marygreen community is quick to recognize, Christminster is aloof. For all of Jude's "spiritual" intentions, his daydreaming belies a self-serving motivation for becoming a Christminster scholar. He dreams of becoming a Doctor of Divinity, a bishop or archdeacon at least (73-74). While he imagines how he might return to better the community, the enjoyment of his anticipated snobbery is undeniable. As a wealthy member of the clerisy, he will stand above the poor inhabitants of Marygreen, paternalistically giving away $£ 4,500$ of his imagined $£ 5,000$ salary (73). The fact that he has no particular idea of where or how the money will be spent suggests that his charitable impulse is more firmly rooted in the desire to occupy the dominant end of a power imbalance than in the wish to interact in any meaningful way with the community. 
Perhaps more important to the form of Jude's fantasy is the university's ahistorical nature. Christminster is temporally phantasmal. It is neither of the here-and-now, but nor does it properly belong to any historical era beyond the nebulous "of old". As Eagleton tells us, this temporal indeterminacy is significant because, lacking its own vitality, Christminster continually demands "nutriment from the labour of the living" to prevent its collapse (39); it becomes a perpetual-motion machine of class domination. However, psychoanalysis contributes another layer of significance. Because Christminster stands apart from history, it exists in a prelapsarian psychical period: it exists prior to the scene of primordial loss (the original "castration") after which full sociality becomes impossible. The timelessness of Christminster renders it a site where subject is not yet barred by the intrusion of the symbolic and, returning to Lacan's theory, the sexual relationship is not yet impossible. Paradoxically, however, this phantastic desire for a point of absolute sociality is at the same time a perverse re-staging of the primal castration. As Žižek writes, "Contrary to the common-sense notion of fantasizing as an indulgence in the hallucinatory realization of desires prohibited by the Law, the phantasmic narrative [... stages] the very act of its installation, of the cut of symbolic castration" (Plague 17, italics in the original). Jude recognizes as much when his fantasy first takes shape: "'It is a city of light,' he said to himself. 'The tree of knowledge grows there.'" (62). Already, he imagines himself as an Adamic figure, at least partially aware that he is doomed to lose the very jouissance promised by the Tree's forbidden fruit, or, more precisely, the erotic rapture that the fruit promises.

Before I return to the erotic implications of this Edenic fantasy, I will first attempt to concretize the fantasy in terms of the novel. As noted earlier, Christminster emerges at the traumatic moment when Jude is confronted with the undeniable 
instability of social relations: this is the fall. After this moment, all that is left is an unattainable surplus, which for the sake of simplicity we can refer to as jouissance. ${ }^{1}$ With Philloston gone, Jude transfers this surplus onto Christminster, rendering it the sublime object of his desire: this is the perverse re-staging. It is crucial to note that the re-staging is not a singular, discrete event that happens once and is completed: it can never be completed. Like Satan in Milton's Paradise Lost, Jude's fall must happen in perpetuity; he must fall "[t]en thousand fathom deep, and to this hour" (II 934). It is precisely for this reason that Jude's perverse fantasy takes a form that must be prohibited. Jude needs the Law to intervene and tell him he cannot attend Christminster; he cannot be a scholar. It must be noted here that "Law" does not simply refer to judicial mechanism of the policeman called upon by the community of Marygreen to prevent his reading while at work (quoted above), nor of the policeman who harasses Jude while he admire the buildings of Christminster (116) -though both externalize the concept nicely. Instead, it refers to an internal mechanism of prohibition, that which regulates access to the objet a. Indeed, as Žižek writes "the object of desire is Law itself" (Plague 17, italics in the original). Finally, we reach the crux of the fantasy, which is that Jude desires prohibition. This is the first element that renders his fantasy properly antisocial. It is the very impossibility of the fantasy that drives Jude. It is the denial of the objet a from which he derives his jouissance. Or, to put it another way, his despair is his enjoyment.

In her chapter on Jude the Obscure, Sumner takes pains to demonstrate that, contrary to standard readings of the time, Jude is a well-balanced and mainly resilient character:

\footnotetext{
${ }^{1}$ While Lacanian psychoanalysis does not figure "surplus" and jouissance as identical to each other, neither are they fully separable. Jouissance can only exist in relation to the subject's proximity to the surplus. If the surplus is the heat of a candle, jouissance is the warmth on the hand that passes over it, or the burning when it comes too near.
} 
In fact, until close to the end, he copes with both his own strong passions and ideas and with the external world in a resilient and tenacious way.... His loss of the will to live at the end seems a fairly reasonable reaction to the loss of everything that makes life meaningful to him. His disintegration is more the result of external pressure than of inner disturbance. (148)

What Sumner fails to comment upon, however, is the frequency with which Jude falls into despair. It does not happen just once, at the end when his children have died and Sue has left him: it happens throughout. We see him disintegrate at the first sign of adversity, flinging himself down on his Latin reader when he first discovers that the words do not render themselves transparent to him (67). It is further telling that Jude's immediate desire is for an impossible social intervention:

Somebody might have come along that way who would have asked him his trouble, and might have cheered him by saying that his notions were further advanced than those of his grammarian. But nobody did come, because nobody does; and under the crushing recognition of his gigantic error, Jude continued to wish himself out of the world. (67)

He longs for another person to tell him that he has already achieved his goal, but this is exactly what his fantasy was designed to preclude. We see that it is not, as Sumner asserts, "external pressure" that causes Jude to despair: it is the internal construction of the fantasy that regulates all social intervention, good or bad. The construct both maximizes external pressure and prevents the social world from helping him attain his goal. He can demand a social intervention only insofar as he knows that it will never happen: "Nobody did come, because nobody does." Thus, the surplus remains and his jouissance is assured. 
Another way to understand this process is in terms of the Freudian "death drive." In the simplest terms, the death drive is that mechanism which regulates the homeostasis of our jouissance. As Freud conceives it in "Beyond the Pleasure Principle," the death drive gives us "pleasure to the degree that it moves beyond a certain point towards complete stability, and unpleasure to the degree that it moves beyond a certain point away from that stability" (134, italics in the original). The death drive is not, as is frequently understood, a suicidal mechanism within our psyche. Quite to the contrary, it is that which demands that we continuously look to the horizon, that we pursue the chimerical object of our desire. The death drive ensures that we remain in this world by constantly reproducing our desire. In terms of Jude's despair, the fact that "nobody does come" allows the drive to persist. There is nothing abnormal in this; however, there is a seemingly pathological short circuit in Jude's particular fantasy. Whereas the typical fantasy orients our drive towards a positive object-an elusive something-Jude's perverse fantasy orients his drive towards nothing. This is the second fundamentally antisocial feature of Jude's Christminster fantasy. It denies futurity; or, rather, it denies the comforting illusion of futurity.

Here I draw upon the recent work of Lee Edelman, who figures this denial of futurity as both sinthomatic and queer (Sinthomosexual, as he terms it). For Edelman, the Lacanian sinthome-the psychical apparatus that allows the individual access to jouissance, not by recognizing a lack in the "Big Other," but by denying the very existence of the "Big Other" as guarantor of meaning-is fundamentally queer (and queerness is fundamentally sinthomatic) in that it is non-procreative. It refuses to participate in the reproduction of a future-oriented fantasy: it "refuses the Symbolic logic that determines the exchange of signifiers [and] admits no translation of its singularity" (35). To understand how Jude's fantasy takes on 
this Sinthomosexual character, we must consider the final crucial element in its form. As noted, Christminster is both socially aloof and temporally remote. Both of these partially reflect the most significant phantasmal characteristic of Christminster, which is that it is not ( $t$ )here. Christminster, as Jude first conceives it, is properly utopian in that it is "no place." As Marroni writes of Philloston's departure, "[t]he beginning in medias res has the function of actualizing the scene of a departure that means a separation from a place" (164). The point being that Jude actualizes the jouissance of his abandonment by attaching it to a place of which he cannot conceive except as separation. Jude's nascent conception of Christminster as the site of absence is immediately solidified when-hoping to give a proper form to his fantasy-he climbs the farmer's ladder to view Christminster with his own eyes. The farmer directs the boy's gaze across the horizon to where Christminster ought to be, but reveals only its absence: "Christminster is out across there, by that clump. You can see it-at least you can on a clear day. Ah, no, you can't now" (56). From here on, Christminster's true form for Jude is not the narrow streets and crumbling masonry of an ancient city; it is a "mirage in the peculiar atmosphere" (57). Since Christminster does not exist except as an ephemera, Jude's fantasy of becoming a part of it is effective a fantasy of nonexistence. To borrow Edelman's figuration, Jude's drive to attain nothing turns the fantasy inside out to reveal its seams (35). It brings him uncomfortably close ("uncomfortably" mainly for those around him) to the nothingness of the Real.

It is not enough to say that, for Jude, Christminster is an empty sign-a signifier without a signified. Better to say it is a perforated sign-a signifier that cannot contain the nothingness of signification. Its incompletion seeps out, thereby calling into doubt the very possibility of completion. The nothingness of Christminster is sinthome par excellence in that it is "immediately permeated with enjoyment-that is, the 
impossible junction of enjoyment with the signifier" (Žižek, Sublime 123). Because Jude's fantasy is already perforated, it lacks the power to properly compel him towards the horizon. It makes no convincing promise of something in the future that is more than nothing. Whereas the normal fantasy looks to the future for self-propagation, the sinthomatic fantasy asserts itself "against futurity, against its propagation, insofar as it would designate an impasse in the passage to the future" (Edelman 33, italics in the original). Jude's fantasy is a source of considerable discomfort for those around him, and must be regulated lest it impinge upon the comforting social fantasies that take haven in the promise of futurity.

And here we arrive at my original assertion that both Jude's scholarly and romantic pursuits must be policed, since they are but facets of the same antisocial fantasy. Once again borrowing from Edelman's figuration, we might as well say they are facets of the same queer fantasy. Indeed, it is the inherent queerness of Jude's primary fantasies - to become a Christminster scholar and, later, to maintain a connubial relationship with his cousin, Sue Bridehead-that society finds so intolerably threatening. Scholars have long noted the parallels between Jude's relationship with Christminster and with Sue Bridehead. In his study of early drafts of Jude the Obscure, John Paterson finds a drift away from the novel's initial focus on Christminster towards Jude's destructive relationship with his cousin. He argues that Sue was originally intended to reflect Jude's interest in Christminster (89). A decade later, Patricia Inham would contend the opposite, asserting that "Jude's longing for Christminster is part of his longing for the unknown girl [Sue]" (167). Whichever side is to be believed, I am certain that Hardy had always envisioned a duality between the fantasies. Moreover, I suggest that the chicken-and-egg origins of Christminster and Sue are immaterial insofar as both are essentially different objets a of the same queer fantasy. As Edelman writes: 
homosexuality, understood as a cultural figure, as the hypostatization of various fantasies that trench on the antisocial force that queerness might better name, is made-that is, both called forth and compelled-to carry the burden of sexuality's demeaning relation to the sinthome, the burden of what Lacan describes as the absence of a sexual relation: the absence that is of a complimentarity to naturalize relations between the sexes insofar as all sexuality suffers from the mark of the signifier as lack. (Edelman 39)

In other words, Jude's relationships with both Christminster and Sue are marked with the stigma of queerness because both refuse to participate in the social fantasy of the sexual relationship-the fantasy that marriage is the coming together of two parts of a whole, uniting signifier and signified.

The homosexual aspect of Jude's fantasy is somewhat more obvious when it takes on the form of Christminster, an exclusively masculine space, which, for Jude, "subsumes the male/female dichotomy within the primal dichotomy of father and mother" (Harding 95). Christminster becomes dangerously hermaphroditic. ${ }^{2}$ The "men of old" (62), in whose company Jude dreams of belonging, simultaneously assume the role of Alma Mater, "Loving Mother" (74). Thus, the sexual relation collapses in on itself, and Christminster becomes a (non-)space which no longer demands, or even permits, an orientation towards the future. It is no wonder then that the moment in which Jude's Christminster fantasy becomes properly hermaphroditic is the moment that the social aggressively intrudes upon it. Nor is it any wonder that the object of intrusion is the original embodiment of the Lacanian barre, "the characteristic part of a barrow-pig," the phallus (Hardy

\footnotetext{
2 "Hermaphroditic" reads "homosexual" in this instance in that, while Christminster is alternately figured as male or female, it is never malefemale. It lacks the complimentarity to which Edleman refers above.
} 
74). As Harding asserts, Arabella's missile serves as a means of castration in that it reveals to Jude the fetishistic nature of his Christminster fantasy: "The penis appears in the scene between Jude and Arabella because the penis is the latent signification of Christminster, and Christminster in turn functions as a fetishized substitute for the nonexistent maternal penis" (97). While I agree with the notion that Arabella's phallus inserts itself as a fetish object, Harding erroneously bases his conclusion on the notion that Christminster is a "normal" fantasy-that, for Jude, the signifier-signified is already barred. Instead, I suggest that the phallus must be inserted at this moment precisely because Christminster is not a fetish. It does not offer Jude the impossible promise of psychic completion. Rather, as I have argued, it promises the opposite.

The same principle holds true of Jude's cousin. As with Christminster, Jude first conceives Sue as a phantom, never truly in the here and now. As he tells her, "you, Sue, are such a phantasmal, bodiless creature, one who-if you'll allow me to say it-has so little animal passion in you, that you can act upon reason in the matter when we poor unfortunate wretches of grosser substance can't" (290). He later says to her, "I have often said, you are absolutely the most ethereal, least sensual woman I ever knew to exist without inhuman sexlessness" (373). Of course, this repeated disavowal of Sue's sexuality rings somewhat disingenuous, even before Jude admits to his carnal desire and coaxes her into bed; but at the same time, his sexual attraction to her is rooted in the same nothingness that draws him to Christminster. Though she is pretty, her real attraction for Jude lies in her "phantasmal," "bodiless," "ethereal" nature, as well as in the fact that their relationship is taboo. For Jude, it seems, the phantasmal and the antisocial are inseparable. Consider, for example, Jude's initial experience with Sue, when he first gazes upon her photograph 
(that he encounters her as a two-dimensional screen neatly underscores the fact of her being a fantasy projection):

[Jude observed] the photograph of a pretty girlish face, in a broad hat, with radiating folds under the brim like the rays of a halo. He asked who she was. His grand-aunt gruffly replied that she was his cousin Sue Bridehead, of the inimical branch of the family. (112)

Thus, Jude constructs his fantasy upon two features: first, that Sue is not quite of this world; second, that she is "inimical." At least part of her allure resides in the fact that he should not have her; that, like Christminster, Sue is a deviant fantasy that demands social prohibition.

The connubial joy, the perverse happiness that Jude derives from his non-marriage with Sue calls into question the illusion of futurity promised by a sanctioned marriage. The couple is dangerous because their unregulated sexuality paradoxically denies the promise of a sexual relationship. It does not defer; it does not "depend on the fantasy of its attainment to come" (Edelman 41, italics in the original). By its very proscription, their sexuality demonstrates the fundamental permeability of the Law. The perverse nature of Jude and Sue's sexuality produces a surplus of jouissance that is eminently readable to those around them, which is why Jude and Sue are continually denied inclusion in any community -it is why, for example, their Christminster landlady intuitively suspects that they are not actually married (359).

Society must police this excessive enjoyment, because a failure to do so threatens to unravel the signifying chain. The ideological structures constructed around the institution of marriage can only maintain themselves so long as the subject's jouissance is held in check. Indeed, as Hardy demonstrates, Jude and Arabella are only legible as a married couple because they make each other miserable: 
The landlord of the lodging, who had heard that they were a queer couple, had doubted if they were married at all, especially as he had seen Arabella kiss Jude one evening when she had taken a little cordial; and he was about to give them notice to quit, till by chance overhearing her one night haranguing Jude in rattling terms, and ultimately flinging a shoe at his head, he recognized the note of ordinary wedlock; and concluding that they must be respectable, said no more. (413)

As the embodiment of the larger social (heterosexual) fantasy, Arabella's function is to bring Jude in line. She must introduce normative objects of desire for Jude to construct a new fantasy around; she must initiate him into a "practical" fantasy that reifies the illusion of symbolic closure. In some ways, Arabella's hard practicality is excusable, perhaps even admirable. As Eagleton notes, "Jude is sickened by Arabella's pig-sticking, but her angry comment, 'Poor folks must live,' has a point and Jude must learn it" (38). Eagleton is right, of course, but Arabella's simple statement of fact is dense with ideological implications: poor folks must live as poor folks. Poor folks must reproduce themselves in order to maintain the structure, if not the actuality, of society-the very society, incidentally, which demands they be poor. More importantly, they must continually defer to some imagined, but never seen, future in which the signifier and signified finally close. Only in this impossible future might they allow Jude's queer fantasy to be fulfilled. 0

\section{Works Cited}

Edelman, Lee. No Future: Queer Theory and the Death Drive.

Durham, NC: Duke UP, 2004. eBook.

Eagleton, Terry. "Thomas Hardy and Jude the Obscure."

Introduction: Jude the Obscure New Wessex Edition (1974). The Eagleton Reader. Ed. Stephen Regan. Malden MA: Blackwell, 1997: 36-48. Print. 
Freud, Sigmund. "Beyond the Pleasure Principle" (1920). The Penguin Freud Reader. Ed. Adam Philips. New York NY: Penguin, 2006: 132-195. Print.

Harding, James M. "The Signification of Arabella's Missile:

Feminine Sexuality, Masculine Anxiety and Revision in Jude the Obscure." The Journal of Narrative Technique. 26.1 (Winter, 1996): 85-111. Print.

Hardy, Thomas. "Candour in English Fiction." Thomas Hardy's Personal Writings. Ed. Harold Orel. London UK: MacMillan. 1966. Print.

---. Jude the Obscure. Ed. Cedric Watts. Toronto ON:

Broadview, 2004. Print.

Ingham, Patricia. "The Evolution of Jude the Obscure." Review of English Studies. 27.106 (February, 1976): 27-37. Print.

Lacan, Jacques. Seminar XX: On Feminine Sexuality, the Limits of Love and Knowledge. Trans. Bruce Fink. New York NY: Norton, 1998. Print.

Maroni, Francesco. Victorian Disharmonies: A Reconsideration of Nineteenth-Century Fiction. Cranbury NJ: John Cabot UP, 2010. Print.

Milton, John. Paradise Lost. Ed. John Leonard. New York NY: Penguin, 2000. Print.

Paterson, John. "The Genesis of Jude the Obscure." Studies in Philology 57.1 (1966): 87-98. Print.

Sumner, Rosemary. Thomas Hardy: Psychological Novelist. London, UK: MacMillan. 1981. Print.

Žižek, Slavoj. The Plague of Fantasies. New York NY: Verso, 1997. Print. 
---. The Sublime Object of Ideology. New York NY: Verso, 1989. Print.

Matthew Risling is a PhD candidate at the University of Toronto. While he is an enthusiastic reader-and, when possible, teacher-of Victorian novels, his primary research focuses on the intersections between science and literature in the eighteenth century. 